Forschungsperspektiven [Електронний ресурс] / R. Franceschini // ForumSprache. - 2000. - № 1. - S. 6267. - Режим доступу: www.forum sprache.de. - Заголовок з екрана. 8. Krumm H. J. Mehrsprachigkeit und europäische Integration [Електронний pecypc] / Н. J. Krumm. - Режим доступу: http://www.eurac.edu/webdav/commul/MEB_Bibliographie_Artikel/Literatur_NEU_Sprachtests/referat_krumm 121202.pdf. - Заголовок з екрана. 9. Siguan M. Die Sprachen im vereinten Europa / M. Siguan. - Tübingen: Stauffenburg, 2001. - 213 S. 10. Vollmer H. Englisch und Mehrsprachigkeit: Interkulturelles Lernen durch Englisch als lingua franca? / H. Vollmer // Mehrsprachiges Europa: Festschrift für Michael Wendt zum 60. Geburtstag / [D. Abendroth Timmer, G. Bach u. a.]. - Tübingen: Günther Narr, 2001. - S. 240-248.

УДК 378.147

Ігор Горошкін

\title{
ПРИНЦИПИ ФОРМУВАННЯ МОВНОЇ ОСОБИСТОСТІ МАЙБУТНІХ ПЕРЕКЛАДАЧІВ
}

Горошкін I. О. Принципи формування мовної особистості майбутніх перекладачів.

У статті на основі вивчення фахової літератури визначено провідні принципи формування мовної особистості майбутніх перекладачів як основні положення функційно-технологічної організації навчання. Особливу увагу приділено принципам компетентнісного підходу, принципам мовної підготовки перекладачів.

Ключові слова: мовна особистість перекладача, загальнодидактичні принципи, принципи компетентнісного підходу, принципи мовної підготовки.

Горошкин И. А. Принципы формирования языковой личности будущих переводчиков.

В статье на основании изучения специальной литературы определены основные принципы формирования языковой личности будущих переводчиков как ведущие положения функционально-технологической организации обучения. Особое внимание уделено принципам компетентностного подхода, принципам языковой подготовки переводчиков.

Ключевые слова: языковая личность переводчика, общедидактические принципы, принципы компетентностного подхода, принципы языковой подготовки.

Goroshkin I. A. Principles of formation of future translators' linguistic identity.

The article based on the study of literature identifies key principles of the linguistic identity of the future interpreters as the leading functional position of functional and technological organization of training. Particular attention is paid to the principles of competence-based approach, the principles of language training for interpreters.

Key words: linguistic personality of interpreter, general didactic principles, principles of competence-based approach, the principles of language training.

Установлення в сучасному суспільстві ринкових відносин, стрімке зростання міжнародних зв'язків не лише розширює межі діяльності перекладачів, а й ставить їх в умови гострої конкуренції, що спричиняє зростання вимог до представників цієї професії. Стаючи ключовою фігурою міжкультурного спілкування та взаєморозуміння, перекладачі виконують соціально важливу комунікативну функцію, роблять можливими міжнародні контакти в політичній, комерційній, науково-технічній та інших галузях, без яких неможливе існування сучасного людства.

Перед викладачами вищих навчальних закладів, які готують фахівців у галузі перекладу, стоїть надзвичайно важливе завдання, що полягає у формуванні мовної особистості майбутніх перекладачів.

Мовна особистість перекладача виявляється у специфічних умовах міжкультурної комунікації, у межах безпосередньої чи опосередкованої взаємодії носіїв різних мов, представників різних культур. У цьому випадку діяльність перекладача $є$ провідним складником комунікації. На думку сучасних дослідників (І. Бахов, Н. Гавриленко, В. Сдобников та ін.), підготовка фахівців виходить далеко за межі мовних проблем. Необхідно «навчити майбутніх перекладачів робити правильні переклади, підготувати їх до професійного життя, озброївши методикою перекладу, познайомивши 3 послідовністю дій перекладача, з необхідними для цього знаннями, уміннями й навичками, з професійними проблемами, можливими під час роботи, із зовнішніми ресурсами, які перекладач може використовувати у своїй діяльності тощо» [2, с. 3]. 
Проблема підготовки майбутніх перекладачів останнім часом перебуває в полі зору лінгвістів (І. Абдулмянова, Н. Валєєва, В. Сдобников, О. Петрова та ін.), психологів (Р. Гладушина, В. Гусєв, І. Зимня, Т. Пастрик, А. Плєхов та ін.), педагогів (Н. Гавриленко, Н. Гальскова, О. Заболотська, І. Плужник, Г. Саприкіна та ін.). Особливої уваги заслуговують студії, у яких досліджуються шляхи і способи формування професійної компетентності майбутніх лінгвістів і перекладачів, зокрема праці І. Бахова, Д. Іщенко, В. Калініна, Т. Колодько, О. Павлик, Т. Пастрик， 3. Підручної， К. Скиби， Н. Соболь， Ж. Таланової, Л. Тархової, О. Шупти, А. Янковця. Питання соціокультурної підготовки у процесі навчання іноземної мови висвітлено в працях Ю. Пассова, С. Тер-Мінасової, Р. Ладо, Х. Браун, П. Ерман, Дж. Хармер, А. Хірш, Дж. Морено, М. Уеллес, А. Р. Райт. Однак проблему формування мовної особистості майбутніх перекладачів стали розробляти порівняно недавно, вона залишається недостатньо вивченою: не отримали належної уваги підходи, принципи, технології формування мовної особистості фахівця в галузі перекладу.

Мета статті: визначити провідні принципи формування мовної особистості студентівмайбутніх перекладачів.

Термін «мовна особистість» введено до наукового обігу російськими лінгвістами (В. Виноградов, Г. Богін, Ю. Караулов). За Ю. Карауловим, це «сукупність здібностей і характеристик людини, які зумовлюють створення і сприйняття нею текстів, що розрізняються: а) ступенем структурно-мовної складності, б) глибиною і точністю відображення дійсності, в) певною цілеспрямованістю» [3]. Л. Струганець називає мовною особистість, виражену в мові (текстах) і через мову реконструйовану в основних своїх рисах на базі мовних засобів, яка акумулює психічний, соціальний, культурний, етичний та інші компоненти, переломлені крізь iii мову й дискурс [7]. Спільним у наведених визначеннях є виокремлення провідної якості мовної особистості - вільне, комунікативно виправдане володіння мовними засобами в усіх життєвих ситуаціях, сформоване почуття відповідальності за свою мовленнєву дію.

Студіювання наукової літератури дало змогу узагальнити різні підходи до виокремлення мовної особистості перекладача, під якою ми розуміємо особистість, здатну пізнавати, описувати, оцінювати навколишню дійсність і брати активну участь у спілкуванні з іншими людьми засобами іноземної мови.

Формування такої особистості стало предметом дослідження педагогів, психологів, соціологів. Отже, є всі підстави вважати дефініцію «мовна особистість» поліпредметною, або інтерпарадигмальною.

Підгрунтям формування мовної особистості є загальнодидактичні принципи - основні положення функційно-технологічної організації навчання, що стають основою для специфічних принципів і в тісному зв'язку регулюють процес професійної підготовки загалом, зумовлюючи зокрема оптимальний вибір і поєднання методів, засобів і форм навчання. Автори посібника «Педагогіка вищої школи» В. Кудіна, М. Соловей, Є. Спіцин вважають, що принципово значущими положеннями для організації педагогічного процесу вищої школи постають принцип особистісної орієнтації, що передбачає опору на особистісні якості (спрямованість, ціннісні орієнтації, особистісний сенс, життєві плани, сформовані настанови, домінуючі мотиви діяльності й поведінки); принцип педагогічного оптимізму, що спирається на позитивне в людині (будь-яка людина має позитивний, здоровий складник, розвиток якого значною мірою визначається ступенем прийняття іншими значущими людьми); принцип орієнтації на ціннісні взаємовідносини, оскільки розвиток особистісних цінностей як соціально, так і індивідуально значущих ідей, образів, понять уважається, без сумніву, однією з пріоритетних основ виховання $[5$, c. 8$]$.

Аналіз наукових студій у галузі теорії й методики професійної освіти (І. Бахов, Н. Гавриленко, С. Перова, І. Плужник, В. Сафонова, С. Шехавцова та ін.) дозволив дійти висновку, що особливо значущими для формування мовної особистості майбутніх перекладачів $\epsilon$ кілька принципів. Розглянемо їх докладніше.

Принцип гуманізації навчального процесу й особистісної орієнтації спрямований на визнання цінності людини як особистості, повагу іiі прав і свобод, орієнтований на загальнолюдські цілі й цінності. Відповідно до зазначеного принципу на заняттях розкривається гуманістичний і гуманітарний потенціал студента, що передбачає розвиток його мовних, інтелектуальних та комунікативних здібностей, ціннісних орієнтацій, мотиваційних 
настанов. Гуманізація в контексті виховання передбачає розвиток ідей педагогіки співробітництва, створення довірливої та сприятливої атмосфери на заняттях з іноземної мови, під час яких студенти могли б почувати себе максимально комфортно.

Принцип системності й послідовності дає змогу представити процес формування мовної особистості майбутнього перекладача як цілісну динамічну систему, що забезпечує єдність навчання, розвитку, виховання й характеризується стійкими взаємозв'язками між цими складниками. Навчати спілкування системно - означає будувати процес навчання з урахуванням такої ієрархії взаємодіючих чинників і умов, що допоможе визначити послідовність у відборі змісту навчального матеріалу, а також закономірність методичної організації. Інтеграція теоретичних знань до певної системи повинна мати логічну структуру, що зумовлює постановку мети і будування плану діяльності, реалізація яких забезпечує очікуваний результат.

Принцип розвивального й виховуючого навчання виражає провідну мету функціонування педагогічної системи, оскільки пов'язує основні педагогічні категорії (виховання, навчання, освіту).

Принцип фундаментальності освіти та іiї професійної спрямованості вимагає правильного співвіднесення орієнтації на широку ерудицію та вузьку спеціалізацію, фундаментальність і технологічність у процесі підготовки і в результатах навчання, загального розвитку особистості й розвитку професійної компетентності майбутніх перекладачів.

Принцип свідомості і творчої активності студентів зумовлює забезпечення викладачем умов, що стимулюють активність студентів, спонукають їх до іншомовної комунікації, максимально розкривають їхні творчі здібності за допомогою використання відповідних форм, методів і засобів навчання - дидактичних ігор, уявних телемостів, презентацій, обговорень тощо.

Принцип послідовності забезпечує перехід від простих форм та методів роботи до більш складних - креативних, що потребують творчого мислення й самостійності, від простих адаптованих текстів до автентичних, оригінальних текстів іноземною мовою.

Принцип науковості передбачає орієнтацію на новітні розробки, передовсім у галузі педагогіки, психолінгвістики, етнопсихології, а також теорії комунікації та міжкультурної комунікації. Надзвичайно важливо створити умови для формування в студентів наукових понять, що відіграють велику роль у становленні мовної особистості перекладача.

Особливої значущості набуває принцип поєднання навчання 3 життям. Атмосферу, максимально наближену до життя, забезпечує використання автентичних іншомовних наочних засобів, а також текстів, що стимулюють студентів до різних видів мовленнєвої діяльності.

У процесі формування мовної особистості майбутніх перекладачів важливу роль посідає принцип емоційності. Як відомо, емоції відіграють велику роль у діяльності людини. Знання, не підкріплені позитивними емоціями, залишаються індиферентними у свідомості студентів. Створення доброзичливої атмосфери на заняттях 3 іноземної мови сприяє розкриттю комунікативного потенціалу студентів, допомагає їм позбутися скутості, страху припуститися помилок. Засобами позитивного емоційного впливу на студентів $\epsilon$ використання віршів і пісень виучуваної мови, фільмів, телепередач, художніх творів, ігор і свят країни, мова якої вивчається, різних форм драматизації та дидактичних ігор. Важливо ознайомити студентів із цікавими фактами біографії відомих перекладачів (Б. Заходера, Г. Кочура, Л. Лунгіної, Б. Пастернака, Б. Тена та інших), що також позитивно впливає на емоційну сферу.

Так, О. Киричук стверджує, що саме на емоційному рівні взаєморозуміння підтримує комфортний психоемоційний фон, оптимальний для здійснення спілкування та спільної комунікативної діяльності, постаючи умовою їхнього повноцінного розвитку [4, с. 48].

Принцип контекстності допомагає «занурити» навчальний процес у контекст майбутньої перекладацької діяльності передовсім через моделювання професійно значущих ситуацій, переклад професійно орієнтованих текстів, що наповнює процес формування мовної особистості майбутніх перекладачів особистісним смислом, розвиває позитивну мотивацію студентів, зумовлює їхню активну життєву позицію.

Принцип соціокультурної відповідності зумовлений тим, що останнім часом у мовній освіті акцент зміщується в бік формування професійної міжкультурної компетентності. Важливим чинником ефективного досягнення мети постає оптимальний відбір i конструювання змісту навчального матеріалу, основним складником якого $є$ досвід емоційноціннісного ставлення до довкілля, до знань, до діяльності, до себе [1; с. 28]. Зміст навчального матеріалу має не тільки забезпечити студентів можливістю оволодіти ще одним способом 
навчання, але й зануритися в нову культуру. Посилення соціокультурного та міжкультурного компонентів повинно стати важливим критерієм відбору змісту навчального матеріалу.

Принцип поєднання індивідуальних і колективних форм навчання зумовлює оптимальне співвідношення різних форм навчання.

У процесі формування мовної особистості майбутніх перекладачів варто враховувати також принципи, що увиразнюють сутність компетентнісного підходу, який останнім часом $\epsilon$ провідним в організації професійної освіти. До них належать принципи мотиваційного забезпечення навчального процесу; ціннісного орієнтування; життєвої доцільності й дієвості знань; спрямування навчання на всебічний i гармонійний розвиток; співробітництва i взаємопідтримки; активності особистості; індивідуалізації; органічної єдності людини, мовлення і процесу навчання.

Принцип мотиваційного забезпечення регулює активність, діяльність, поведінку студентів. Будь-яка взаємодія викладача зі студентом буде ефективною за умови підтримки позитивної мотивації до навчання. Педагогікою накопичено значний арсенал шляхів і засобів формування інтересу до предмета, зокрема позитивне ставлення педагога до предмета і суб'єктів навчання, новизна матеріалу, використання мультимедійних засобів, створення ситуацій успіху тощо. Важливо знайти найбільш ефективні в кожній конкретній ситуації.

Принцип ціннісного орієнтування спрямований на усвідомлення студентами життєвого досвіду. Відповідно, ціннісні орієнтації, що були усвідомлені особистістю, стають для студентів індикатором, який допомагає зіставити власні інтереси, вчинки 3 загальноприйнятими. Формування ціннісних орієнтацій - процес надзвичайно складний, на який впливає багато чинників, насамперед освітнє середовище, у змісті якого закладено систему цінностей, які мають опанувати студенти. Цей принцип зумовлює розуміння ціннісних оріснтацій перекладачів, дотримання професійної гідності, формування почуття відповідальності за достовірність перекладеної інформації.

Принцип життєвої доцільності й дієвості знань зумовлює добір змісту навчання й допомагає побудувати навчальний процес 3 урахуванням вимог майбутньої професійної перекладацької діяльності.

Принцип спрямування навчання на всебічний і гармонійний розвиток особистості студента спрямовує викладачів на рівномірний розвиток інтелектуальної, емоційної, вольової та фізичної сфер студентів.

Особливо значущим уважаємо принцип співробітництва і взаємної підтримки, що, поперше, визначає викладача і студентів рівноправними суб'єктами навчального процесу, готовими до продуктивного діалогу, по-друге, стимулює студентів до надання взаємодопомоги, взаємопідтримки. Імпульсом до розвитку особистості є притаманна кожній особистості потреба в розвиткові, що реалізується в процесі взаємодії 3 іншими особистостями, і лише посередництвом взаємодії особистість взаємодіє з суспільством.

Принцип активності особистості передбачає стимулювання прагнення майбутніх перекладачів розширювати сферу власної діяльності.

Принцип індивідуалізації зумовлює послідовне ставлення педагога до студента як до унікальної особистості, розроблення індивідуальної траєкторії навчання. У зв'язку з цим Л. Шестов писав: «... Яка користь у загальних правилах. Ніякої. Природа владно вимагає від кожного з нас індивідуальної творчості» [8, с. 164-165].

Під час організації цілеспрямованої роботи 3 формування мовної особистості майбутніх перекладачів значущим постає опір на принципи, визначені І. Баховим: 1) принцип пізнання і врахування ціннісних культурних універсалій; 2) принцип культурно пов'язаного співвивчення іноземної й рідної мов; 3) принцип етнографічного підходу до визначення культурних компонентів значень явищ лінгвістичного і нелінгвістичного характеру; 4) принцип мовленнєвоповедінкових стратегій; 5) принцип усвідомлення психологічних процесів і станів, пов'язаних із міжкультурним спілкуванням, що $\epsilon$ результатом «переживання» культурних феноменів $\mathrm{i}$ пов'язаних $з$ ними способів пізнання (внаслідок застосування цього принципу досягається «свідома компетенція»); 6) принцип керованості власним психологічним станом і станом невизначеності того, що відбувається; 7) принцип емпатійного ставлення до учасників міжкультурного спілкування; 8) принцип діалогу культур і цивілізацій; 9) принцип домінування методично прийнятних проблемних культурознавчих завдань [1, с. 17]. Як бачимо, виокремлені 
принципи спрямовані на формування соціокультурного складника мовної особистості перекладачів. Хоч ці принципи дослідник виокремив у контексті підготовки перекладачів англійської мови, ми вважаємо їх ефективними у процесі професійної підготовки перекладачів різних мов, оскільки вони враховують змістовий і технологічний аспекти навчання.

О. Поршньова визначила принципи мовної підготовки перекладачів, зокрема принцип практичної спрямованості, організації орієнтовної діяльності студента, збагачення суб'єктного мовленнєвого досвіду й тезаурусу, цілісності, послідовного моделювання змісту професійної діяльності, системності, сконцентрованості дій, гнучкості, динамічності [6].

Принципи завжди постають в органічному взаємозв'язку, доповнюючись та зумовлюючись; підтверджені змістом навчання (реалізовані у програмах і підручниках), покладені в основу навчального процесу (організації аудиторної, позааудиторної, самостійної роботи студентів, застосування методів і прийомів навчання, добору дидактичного матеріалу тощо). Комплекс схарактеризованих принципів сприяє формуванню мовної особистості майбутніх перекладачів.

Перспективи подальшого дослідження вбачаємо в розробленні педагогічних умов формування мовної особистості майбутніх перекладачів.

\section{Література}

1. Бахов I. С. Формування міжкультурної професійної компетентності у студентів-перекладачів: [монографія] / І. С. Бахов. - К. : ДП ВД «Персонал», 2009. - 268 с. 2. Гавриленко Н. Н. Теория и методика обучения переводу в сфере профессиональной коммуникации / Н. Н. Гавриленко. - Кн. 1. М. : Научно-техническое общество имени академика С. И. Вавилова, 2009. - 178 с. З. Караулов Ю. Н. Русский язык и языковая личность / Ю. Н. Караулов. - М. : Наука, 1987.- 264 с. 4. Киричук О. В. Основи психології: [підручник для студ.] / О. В. Киричук, В. А. Романець, В. О. Татенкова та ін. - [3-є вид.]. - К. : Либідь, 2004. - 632 с. 4. Кудіна В. В. Педагогіка вищої школи / [Кудіна В. В., Соловей М. І., Спіцин Є. С.]. - К. : Ленвіт, 2006. - 170 с. 5. Поршнева Е. Р. Междисциплинарные основы базовой лингвистической подготовки специалиста-переводчика : автореф. дис. на соискание науч. ступеня д-ра пед. наук: спец. 13.00.08 «Теория и методика профессионального образования»/ Е. Р. Поршнева. - Казань, 2004. - 42 с. 6. Струганець Л. Теоретичні основи культури мови: [навч. посіб. для студ. філол. фак-тів] / Л. Струганець. - Тернопіль, 1997. - 96 с. 7. Шестов Л. Апофеоз беспочвенности. Опыт адогматического мышления / Л. Шестов - Л. : ЛГУ, 1991. - 216 с.

\section{РЕСУРСНЕ ЗАБЕЗПЕЧЕННЯ РОЗВИТКУ КОМУНІКАТИВНОӤ КОМПЕТЕНЦЇ̈ МАЙБУТНЬОГО КЕРІВНИКА ЗАКЛАДУ ОСВІТИ ЯК СКЛАДНИКА УПРАВЛІНСЬКО-ПЕДАГОГІЧНОЇ КУЛЬТУРИ}

Гуменникова Т. Р. Ресурсне забезпечення розвитку комунікативної компетенції майбутнього керівника закладу освіти як складника управлінсько-педагогічної культури.

У статті презентовано шляхи розвитку комунікативної компетенції майбутнього керівника закладу освіти. В експериментальній роботі змодельовано та апробовано ресурси навчального середовища ВНЗ в Україні, який готує керівників закладів освіти. Визначено етапи наскрізної магістерської підготовки щодо підвищення рівня володіння іноземною мовою в напрямку вдосконалення професійної діяльності.

Ключові слова: магістратура, керівник закладу освіти, рівень володіння мовою, комунікативна компетенція, професійне спілкування.

Гуменникова Т. Р. Ресурсное обеспечение развития коммуникативной компетенции будущего руководителя учебным заведением как составляющей управленческо-педагогической культуры.

В статье презентованы пути развития коммуникативной компетенции будущего руководителя учебным заведением. Определены и апробированы потенциальные ресурсы высшего учебного заведения, которое готовит руководителей учебных заведений в ракурсе исследовательской проблемы. Экспериментально доказана эффективность этапов магистерской подготовки относительно повышения уровня владения иностранным языком, как условия совершенствования профессиональной деятельности.

Ключевые слова: магистратура, руководитель учебным заведением, уровень владения языком, коммуникативная компетенеция, профессиональное общение. 